\title{
Inhalt
}

Bruce Gordon and Randolph C. Head

Zwingli's Ambivalent Anniversary 2019: An Ereignisbericht . . . . . . . 7

Claudio César Rizzuto

The Comunero Revolt and Luther's Impact on Castile: Rebellion, Heresy, and Ecclesiastical Reform Impulses, $1520-1521 \ldots \ldots$

Daniel Lehmann

"Such an Illumination Cannot Occur": Anthonius Margaritha, the Reformation, and the Polemic against the Jews . . . . . . . . . . .

Terence McIntosh

Luther, Melanchthon, and the Specter of Zwingli during the Diet of Augsburg in $1530 \ldots \ldots \ldots \ldots \ldots \ldots$

\section{Zachary Purvis}

When Melanchthon Became a Freemason: The So-Called 1535 Charter of Cologne and Its Long Aftermath . . . . . . . . . . . . . . . . . 109

\section{Mark A. Hutchinson}

The Question of Obedience and the Formation of Confessional Identity in the Irish Reformation . . . . . . . . . . . . . . . . .

Steven W. Tyra

"Neither the Spirit Without the Flesh": John Calvin's Greek Doctrine of the Beatific Vision . . . . . . . . . . . . . . . . . . . . . . 170

\section{Louise Vermeersch}

Mennonite Martyrs and Multimedia: On the Form and Function of Intermediality in Reformation Communication . . . . . . . . . . . . . . . 194

Yves Krumenacker

La coiffure de Charlotte Arbaleste . . . . . . . . . . . . . . 217

Jaap Geraerts

Caught between Canon and Secular Law: Catholic Marriage Practices in the Dutch Golden Age . . . . . . . . . . . . . . . . . . . . 246

Christine Kooi

The Synod of Dordrecht after Four Hundred Years . . . . . . . . . . . 289 
Markus Friedrich

Reformation History between Accident, Ambition, and Anguish: Barthold Nicolaus Krohn (1722-1795) and his Project for a General History of Anabaptism . . . . . . . . . . . . . . . . . . . . 301 